\title{
Ephrin-A Binding and EphA Receptor Expression Delineate the Matrix Compartment of the Striatum
}

\author{
L. Scott Janis, Robert M. Cassidy, and Lawrence F. Kromer \\ Department of Cell Biology and Interdisciplinary Program in Neuroscience, Georgetown University Medical Center, \\ Washington, DC 20007
}

The striatum integrates limbic and neocortical inputs to regulate sensorimotor and psychomotor behaviors. This function is dependent on the segregation of striatal projection neurons into anatomical and functional components, such as the striosome and matrix compartments. In the present study the association of ephrin-A cell surface ligands and EphA receptor tyrosine kinases (RTKs) with the organization of these compartments was determined in postnatal rats. Ephrin-A1 and ephrin-A4 selectively bind to EphA receptors on neurons restricted to the matrix compartment. Binding is absent from the striosomes, which were identified by $\mu$-opioid receptor immunostaining. In contrast, ephrin-A2, ephrin-A3, and ephrin-A5 exhibit a different mosaic binding pattern that appears to define a subset of matrix neurons. In situ hybridization for EphA RTKs reveals that the two different ligand binding patterns strictly match the mRNA expression patterns of EphA4 and EphA7. Ligand-receptor binding assays indicate that ephrin-A1 and ephrin-A4 selectively bind EphA4 but not EphA7 in the lysates of striatal tissue. Conversely, ephrin-A2, ephrin-A3, and ephrin-A5 bind EphA7 but not EphA4. These observations implicate selective interactions between ephrin-A molecules and EphA RTKs as potential mechanisms for regulating the compartmental organization of the striatum.

Key words: striosomes; matrix; EphA4; EphA7; tyrosine kinase receptor; development; rat; prosencephalon
The striatum is a major integrative relay center for limbic and neocortical inputs and plays a critical role in the regulation of sensorimotor and psychomotor behaviors (for review, see Marsden, 1981; Alheid and Heimer, 1988; Albin et al., 1989; Carlsson and Carlsson, 1990; Penney and Young, 1993; Parent and Hazrati, 1995). This integrative function is associated with the organization of striatal projection neurons into distinct compartments, such as the striosomes and matrix (Gerfen, 1984; Graybiel, 1984; for review, see also Gerfen, 1992; Heimer et al., 1995). Within the striosome and matrix compartments, there is a unique topographic organization of the corticostriatal and nigrostriatal afferents (Gerfen, 1989; Kincaid and Wilson, 1996), which is recapitulated in the segregation of efferent projections from neurons located in the striosomes versus the matrix (for review, see Gerfen, 1992; Heimer et al., 1995). These two compartments also are readily distinguished on the basis of unique biochemical characteristics. In most adult mammals, acetylcholinesterase activity and somatostatin-immunoreactive fibers are primarily localized to the matrix, as are GABAergic neurons that coexpress calbindin. In contrast, $\mu$-opioid receptors, cholinergic muscarinic receptors, and substance $\mathrm{P}$ fibers are concentrated in the striosomes (Herkenham and Pert, 1981; Graybiel, 1984; Nastuk and Graybiel, 1985, 1988; Gerfen et al., 1987; Desban et al., 1989; Schoen and Graybiel, 1992; for review, see Gerfen, 1992).

Received Jan. 13, 1999; revised March 23, 1999; accepted April 2, 1999.

This research was supported by National Institutes of Health Grant HD07549. We wish to thank Dr. Nicholas Gale at Regeneron (Tarrytown, NY) for kindly providing the ephrin-A-Fc fusion proteins and Drs. Richard Lindberg and G. M. Fox at Amgen (Thousand Oaks, CA) for their generosity in supplying the EphA antibodies and cDNA used in these experiments.

Correspondence should be addressed to Dr. Lawrence Kromer, Department of Cell Biology, Georgetown University Medical Center, 3900 Reservoir Road, NW, Washington, DC 20007.

Dr. L. Scott Janis and Robert M. Cassidy contributed equally to this work. Copyright (C) 1999 Society for Neuroscience $0270-6474 / 99 / 194962-10 \$ 05.00 / 0$
Studies of the ontogenic development of the striatum along with its afferent innervation indicate that the segregation of neurons into the striosome and matrix compartments occurs between embryonic day 20 and postnatal day 10 (Murrin and Ferrer, 1984; Lanca et al., 1986; Fishell and van der Kooy, 1987; van der Kooy and Fishell, 1987; Voorn et al., 1988; Murrin and Zeng, 1989, 1990; Arnauld et al., 1995). The initial indication that striatal neurons are beginning to segregate into striosomes is the association of islands of dopamine afferents from the substantia nigra with aggregates of early-generated striatal neurons (Loizou, 1972; Olson et al., 1972; Graybiel, 1984; Murrin and Ferrer, 1984; van der Kooy and Fishell, 1987). This segregation of neurons into compartments results in a characteristic mosaic pattern within the striatum in which the dendritic arbors of the spiny neurons are mainly confined to their respective compartments (Wilson and Groves, 1980; Bishop et al., 1982; Penny et al., 1988; Walker et al., 1993; for review, see Parent and Hazrati, 1995).

Although the molecular mechanisms that direct the segregation of striatal neurons into restricted compartments are unknown, members of the Eph subfamily of receptor tyrosine kinases (RTKs) and their ligands, ephrins, are thought to play important roles in restricting cell migration in other regions of the nervous system during development. For example, the segmental organization of the somites and the restricted pattern of neural crest migration are correlated with the alternating pattern of ephrin and Eph RTK expression in the somites and the expression of Eph receptors by neural crest cells (Bergemann et al., 1995; Flenniken et al., 1996; Wang and Anderson, 1997; Durbin et al., 1998; for review, see Flanagan and Vanderhaeghen, 1998). Moreover, disruption of Eph signaling alters neural crest cell migration and somite formation (Krull et al., 1997; Durbin et al., 1998). Within the developing hindbrain, the alternating expres- 
sion of ephrins and Eph RTKs in the rhombomeres (GilardiHebenstreit et al., 1992; Nieto et al., 1992; Becker et al., 1994; Henkemeyer et al., 1994; Taneja et al., 1996) also is thought to restrict cell migration between rhombomeres because interfering with EphA4 receptor activation results in an abnormal migration of cells across segmental boundaries between adjacent rhombomeres (Xu et al., 1995; for review, see Friedman and O'Leary, 1996; Flanagan and Vanderhaeghen, 1998).

Ephrins and Eph RTKs can be subdivided into two classifications (A and B subgroups) based on ligand attachment to the cell membrane and the specificity of receptor-ligand interactions (for review, see Gale and Yancopoulos, 1997; Flanagan and Vanderhaeghen, 1998; Zhou, 1998). The three known members of the ephrin-B subfamily are transmembrane molecules that exhibit promiscuous binding to six EphB RTKs (Gale et al., 1996b; Holland et al., 1996; Bruckner et al., 1997). The five ephrin-A ligands are attached to the cell membrane by a glycosylphosphatidylinositol moiety, and they exhibit varying degrees of affinity for eight different EphA RTKs (Davis et al., 1994; Gale et al., 1996b; Ciossek and Ullrich, 1997; Monschau et al., 1997; Park and Sanchez, 1997; for review, see Gale and Yancopoulos, 1997). Binding of ephrins to their Eph RTKs induces receptor autophosphorylation and activates intracellular signaling cascades that result in a destabilization of the actin cytoskeleton (Ellis et al., 1996; Bruckner et al., 1997; Holland et al., 1997; Meima et al., 1997; Park and Sanchez, 1997; Zisch et al., 1998). This mechanism is thought to be responsible for initiating growth cone collapse and inhibiting cellular process outgrowth and cell migration in culture after activation of Eph receptors (Gao et al., 1996, 1998; Meima et al., 1997; Davenport et al., 1998). On the basis of these observations plus recent in situ hybridization and immunohistochemical data indicating that certain EphA receptors are present in the developing and adult striatum (Maisonpierre et al., 1993; Mori et al., 1995a,b; Cassidy et al., 1996; Martone et al., 1997; Zhang et al., 1997), we initiated a series of experiments to determine whether members of this subfamily of RTKs and their cognate ephrin-A ligands are associated with the compartmental organization of neurons within the striatum.

\section{MATERIALS AND METHODS}

Animals and tissue preparation. Timed pregnant female Sprague Dawley rats were obtained from Zivic-Miller breeders. The first $24 \mathrm{hr}$ after the vaginal plug was positive was designated as embryonic day 0 (E0), and the first $24 \mathrm{hr}$ after birth was designated postnatal day 0 (P0). For immunohistochemical examination, rats were anesthetized with Nembutal and perfused intracardially with $4 \%$ paraformaldehyde in $0.1 \mathrm{~m}$ phosphate buffer. After perfusion, the brain was removed, post-fixed for $1 \mathrm{hr}$ in $4 \%$ buffered paraformaldehyde $\left(4^{\circ} \mathrm{C}\right)$, and then cryoprotected in $20 \%(\mathrm{w} / \mathrm{v})$ sucrose for $24 \mathrm{hr}$ at $4^{\circ} \mathrm{C}$. The brain was frozen on dry ice and stored at $-80^{\circ} \mathrm{C}$. Tissue sections $(16-20 \mu \mathrm{m})$ were cut using a cryostat microtome and mounted on Superfrost Plus slides.

For tissue dissections, postnatal rats were anesthetized with Nembutal before decapitation. The brain was rapidly removed and placed on a cold plate $\left(4^{\circ} \mathrm{C}\right)$. Under a surgical microscope, the brain was positioned ventral side up, and one transverse cut was made through the caudal aspect of the olfactory tubercle with a second transverse cut placed rostral to the infundibular stalk. The striatum was then visualized within this coronal tissue slab, dissected free from the external capsule and nucleus accumbens/basal forebrain, immediately frozen on dry ice, and stored at $-80^{\circ} \mathrm{C}$

Fusion proteins and antibodies. Ephrin-A-Fc fusion proteins were kindly provided by Dr. Nicholas Gale (Regeneron, Tarrytown, NY). Construction and preparation of these fusion proteins have been described previously (Davis et al., 1994; Gale et al., 1996b). The polyclonal antibodies against EphA4 and EphA7 (generously provided by Dr. Rick Lindberg, Amgen, Thousand Oaks, CA) were prepared by immunizing rabbits with the peptides MRTQMQQMHGRMVPV (corresponding to the 15 C-terminal amino acids of HEK8, renamed EphA4) and QMLHLHGTGIQV (corresponding to the $12 \mathrm{C}$-terminal amino acids of HEK11, renamed EphA7), respectively (Fox et al., 1995). The immune serum was affinity-purified using the respective peptide antigen coupled to a SulfoLink coupling gel column (Pierce, Rockford, IL). Crossreactivity of these antibodies to several members of the EphA receptor family was evaluated, and each antibody was found to be specific for its receptor (Janis and Kromer, 1997). Polyconal $\mu$-opioid receptor antibodies were purchased from Incstar Corporation (Stillwater, MN).

Ligand binding histochemistry and immunohistochemistry. Ephrin-A-Fc fusion proteins were used to determine the binding patterns for the five different ephrin-A ligands. For this procedure, mounted sections were preincubated in blocking solution containing $0.1 \mathrm{M} \mathrm{PBS}, 10 \%$ goat serum, $2 \% \mathrm{BSA}$, and $0.02 \% \mathrm{Na}$ azide for $30 \mathrm{~min}$ at room temperature. The sections were then incubated for 1-2 hr at room temperature either with COS cell supernatants containing ephrin-A-Fc or with purified ephrinA-Fc fusion proteins at a concentration of $2 \mu \mathrm{g} / \mathrm{ml}$. Sections were rinsed three times for $10 \mathrm{~min}$ each in PBS, fixed in $4 \%$ buffered paraformaldehyde for $30 \mathrm{~min}$, and rinsed again in PBS. Secondary antibodies (goat anti-human IgG conjugated to biotin; Chemicon, Temecula, CA) were added at a 1:500 dilution and incubated for $1 \mathrm{hr}$ at room temperature. Fusion protein binding sites were then visualized using the Vectastain elite ABC kit (Vector Laboratories, Burlingame, CA) per the manufacturer's instructions.

The immunohistochemical identification of $\mu$-opioid receptors was performed by washing sections in blocking solution for $30 \mathrm{~min}$ at room temperature and then incubating for $48 \mathrm{hr}$ at $4^{\circ} \mathrm{C}$ in PBS containing $5 \%$ goat serum, $1 \% \mathrm{BSA}, 0.02 \% \mathrm{Na}$ azide, and polyclonal anti- $\mu$-opioid receptor $(1: 10,000)$. Sections were rinsed three times for 10 min each in PBS and then incubated in biotinylated anti-rabbit IgG (diluted 1:500) for $1 \mathrm{hr}$ at room temperature. After being rinsed three times for $10 \mathrm{~min}$ each in PBS, sections were visualized using the Vectastain elite ABC kit (Vector Laboratories).

Ligand-receptor binding assay and Western blotting. Tissue samples were lysed in ice-cold $\left(4^{\circ} \mathrm{C}\right)$ lysis buffer [50 mM Tris-HCl, $\mathrm{pH}$ 7.6, containing $150 \mathrm{~mm} \mathrm{NaCl}, 1 \% \mathrm{NP}-40,10 \%$ glycerol, $10 \mathrm{~mm} \mathrm{NaF}, 10 \mu \mathrm{g} / \mathrm{ml}$ aprotinin, $1 \mu \mathrm{g} / \mathrm{ml}$ leupeptin, $10 \mu \mathrm{g} / \mathrm{ml}$ pepstatin, $0.4 \mathrm{mg} / \mathrm{ml} \mathrm{4-(2-aminoethyl)-}$ benzenesulfonyl fluoride, and $0.1 \mathrm{~mm}$ sodium orthovanadate]. The protein concentration of the lysates was estimated using the method of Bradford (with reagents from Bio-Rad, Richmond, CA), and the total protein content between samples was equalized. Ephrin-A-Fc ligand binding assays were performed by incubating each sample overnight at $4^{\circ} \mathrm{C}$ either with $\mathrm{COS}$ cell supernatants containing ephrin-A-Fc or with purified ephrin-A-Fc fusion proteins at $2 \mu \mathrm{g} / \mathrm{mg}$ of total lysate protein. Protein A-Sepharose (Pharmacia, Piscataway, NJ) was then added to precipitate the ligand-receptor complex via its binding to the $\mathrm{Fc}$ component of the ephrin-A-Fc fusion protein. The precipitated receptorligand-protein A complex was washed in three changes of cold $\left(4^{\circ} \mathrm{C}\right)$ lysis buffer, and the EphA receptor and ephrin-A ligand proteins were dissociated by heating at $100^{\circ} \mathrm{C}$ for $5 \mathrm{~min}$ in sample buffer (2\% SDS, $100 \mathrm{~mm}$ DTT, $10 \%$ glycerol, and $0.02 \%$ bromophenol blue). Proteins were resolved on $7.5 \%$ SDS polyacrylamide gels and transferred to nitrocellulose filters as described previously (Fryer et al., 1996). Filters were blocked with $2 \%$ bovine serum albumin in $0.1 \mathrm{M}$ PBS and then incubated overnight at $4^{\circ} \mathrm{C}$ with affinity-purified polyclonal EphA4 or EphA7 antibodies $(0.1 \mu \mathrm{g} / \mathrm{ml})$. The filters were developed using ECL-Plus chemiluminescence reagents (Amersham, Arlington Heights, IL) with secondary antibodies from Boehringer Mannheim (Indianapolis, IN).

In situ hybridization. Probes used for in situ hybridization were a 275 base pair (bp) EphA4 riboprobe directed against nucleotides (nt) 11861460 (GenBank accession number S57168) and a 263 bp EphA7 riboprobe directed against nt 1287-1549 (GenBank accession number U21954). Plasmids (pGEM) containing cDNA were linearized, and ${ }^{35}$ S-rUTP-labeled riboprobes were transcribed using the SP6/T7 Riboprobe System (Promega, Madison, WI) according to the manufacturer's protocol. Mounted tissue sections (16 $\mu$ m thick) were rehydrated, treated with $0.2 \mathrm{~N} \mathrm{HCl}$, washed, treated with proteinase $\mathrm{K}(10 \mu \mathrm{g} / \mathrm{ml})$ followed by $0.05 \%$ acetic anhydride in triethanolamine, and then dehydrated. Sections were hybridized for $24-48 \mathrm{hr}$ at $55^{\circ} \mathrm{C}$ in hybridization buffer $(50 \%$ formamide, $300 \mathrm{~mm} \mathrm{NaCl}, 20 \mathrm{~mm}$ Tris, $10 \mathrm{~mm} \mathrm{Na}_{2} \mathrm{HPO}_{4}, 5 \mathrm{~mm}$ EDTA, $1 \times$ Denhardt's, $10 \%$ dextran sulfate, $200 \mathrm{~mm}$ DTT, and $0.5 \mathrm{mg} / \mathrm{ml}$ yeast RNA) with $10^{5} \mathrm{cpm}$ of probe in a humid environment. The slides were soaked in $5 \times \mathrm{SSC}(750 \mathrm{~mm} \mathrm{NaCl}$ and $75 \mathrm{~mm} \mathrm{Na}$ citrate) to remove coverslips and then in $2 \times \mathrm{SSC}$ at $55^{\circ} \mathrm{C}$ for $30 \mathrm{~min}$. After treatment with RNase A $(20 \mu \mathrm{g} / \mathrm{ml})$ for $30 \mathrm{~min}$ at $37^{\circ} \mathrm{C}$, sections were washed in $2 \times \mathrm{SSC}$, 
Figure 1. Adjacent coronal sections through the striatum of a P6 rat incubated with four different ephrin-A-Fc fusion proteins. $A$, Ephrin- $\mathrm{A} 4-\mathrm{Fc}$ $(E f n-A 4-F c)$ displays extensive binding to large areas of the striatal neuropil (arrowheads) that are perforated by smaller regions exhibiting less dense binding (asterisks). A prominent continuous region of binding is consistently observed along the dorsal aspect of the striatum (arrows). B, C, EphrinA5-Fc $(E f n-A 5-F c)(B)$ and ephrin$\mathrm{A} 2-\mathrm{Fc}(E f n-A 2-F c)(C)$ exhibit an identical binding pattern within the striatum, which differs from that observed for ephrin-A4-Fc $(A)$. Both ephrin-A2-Fc and ephrin-A5-Fc exhibit low levels of binding to large areas of the striatum (asterisks). These areas are superimposed on the smaller regions that lack ephrin-A4-Fc binding (asterisks). As with ephrin-A4-Fc, these ligands exhibit a dense band of binding along the dorsal aspect of the striatum (arrows). Furthermore, these ligands exhibit more restrictive binding to areas of striatal neuropil (arrowheads) that are located within regions exhibiting ephrin-A4-Fc binding. $D$, The ephrin-A3-Fc $(E f n-A 3-F c)$ binding pattern is most similar to that observed for ephrin-A2-Fc and ephrin-A5-Fc, although there is less noticeable differentiation between striatal areas with high (arrows and arrowheads) versus low binding (asterisks). Scale bar, $500 \mu \mathrm{m}$.
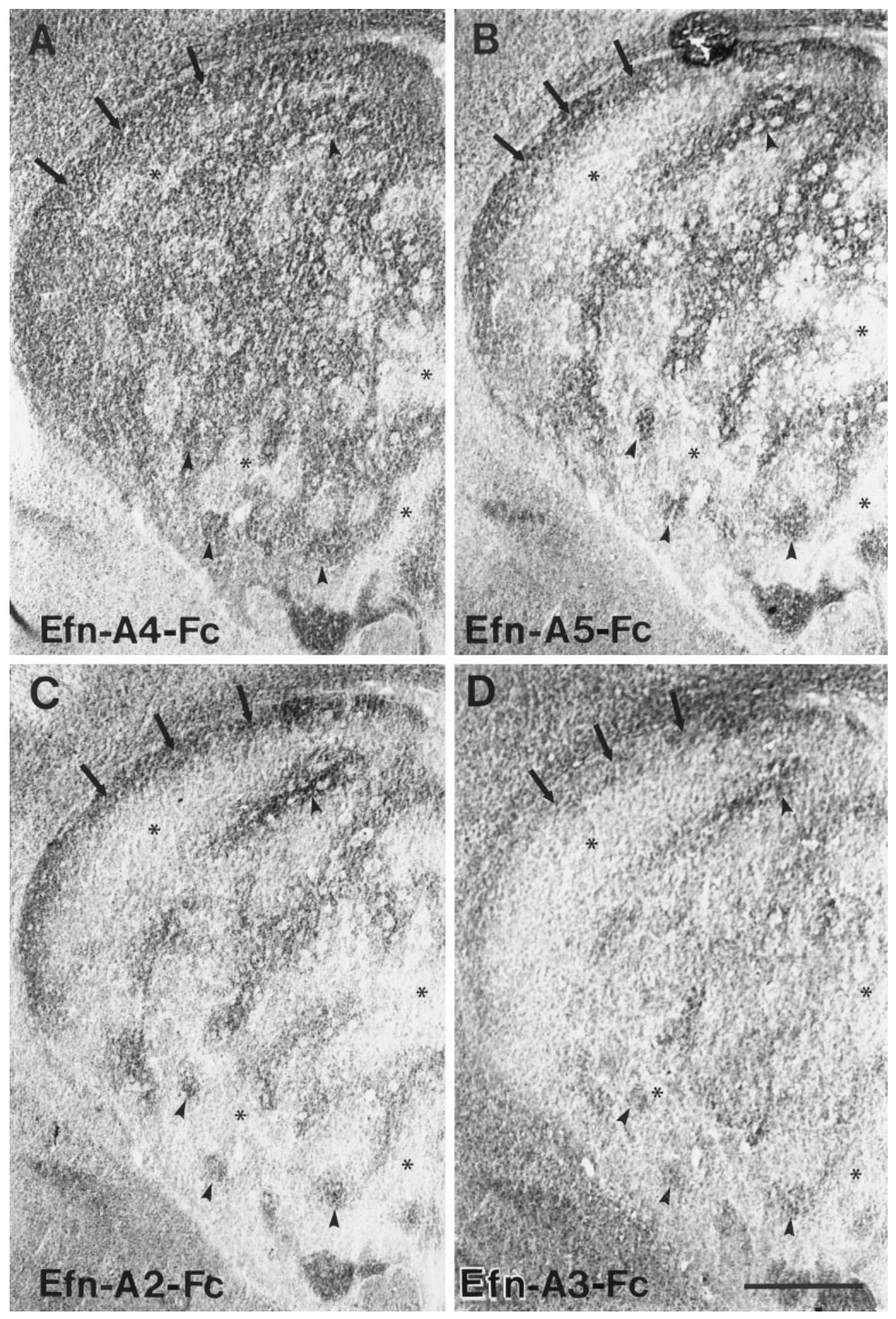

$1 \times$ SSC, and $0.5 \times$ SSC for 30 min each, dehydrated, and air-dried. Slides were dipped in NTB2 autoradiographic emulsion (Eastman Kodak, Rochester, NY) and exposed at $4^{\circ} \mathrm{C}$ for $8-16 \mathrm{~d}$. After the emulsion was developed, sections were dehydrated, and the slides were coverslipped using Permount.

\section{RESULTS}

\section{Comparison of ephrin-A ligand binding in the striatum}

To determine whether there was any differential distribution of binding sites for ephrin-A ligands within the postnatal striatum, we incubated adjacent sections through the striatum of postnatal
(P4-P15) rats with fusion proteins containing the extracellular domain of the five different ephrin-A ligands attached to the Fc fragment of human IgG. Incubation of adjacent tissue sections with each ephrin-A-Fc resulted in two distinct mosaic binding patterns in the striatum (Figs. 1, 2). Ephrin-A1-Fc and ephrinA4-Fc exhibited a similar, highly specific binding to EphA receptors located on cells and cellular processes that were distributed throughout large areas of the striatum (Figs. $1 A, 2$ ). Interspersed within these areas of ephrin-A1 and ephrin-A4 binding were smaller patches of neuropil that exhibited little, if any, ligand 

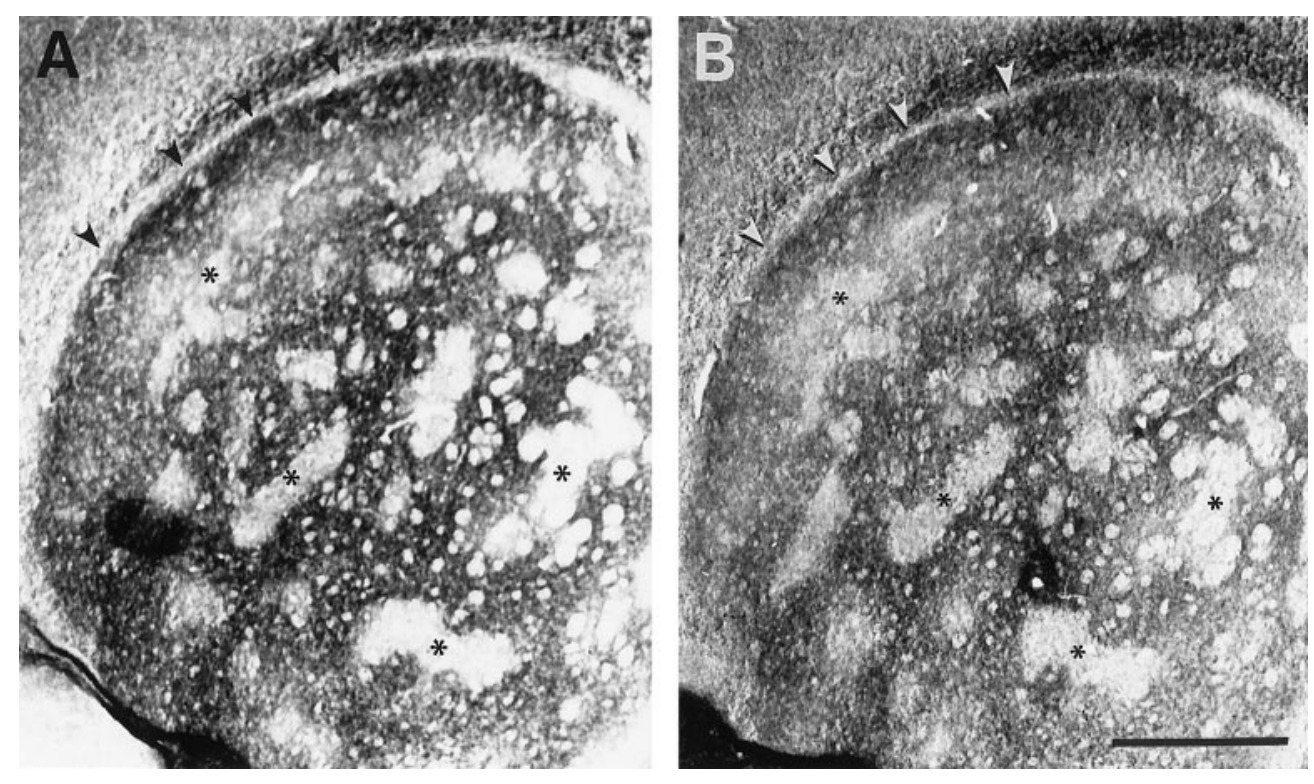

Figure 2. Adjacent coronal sections of a $\mathrm{P} 7$ striatum incubated with ephrin$\mathrm{A} 4-\mathrm{Fc}(A)$ and ephrin-A1-Fc $(B)$ fusion proteins. Both ligands produce an identical mosaic binding pattern within the striatum. Small patches with little or no binding (asterisks) are superimposed in adjacent sections for both ligands. In addition, there is a narrow band of neuropil located below the corpus callosum and external capsule (arrowheads) that lacks binding. Scale bar, $500 \mu \mathrm{m}$.
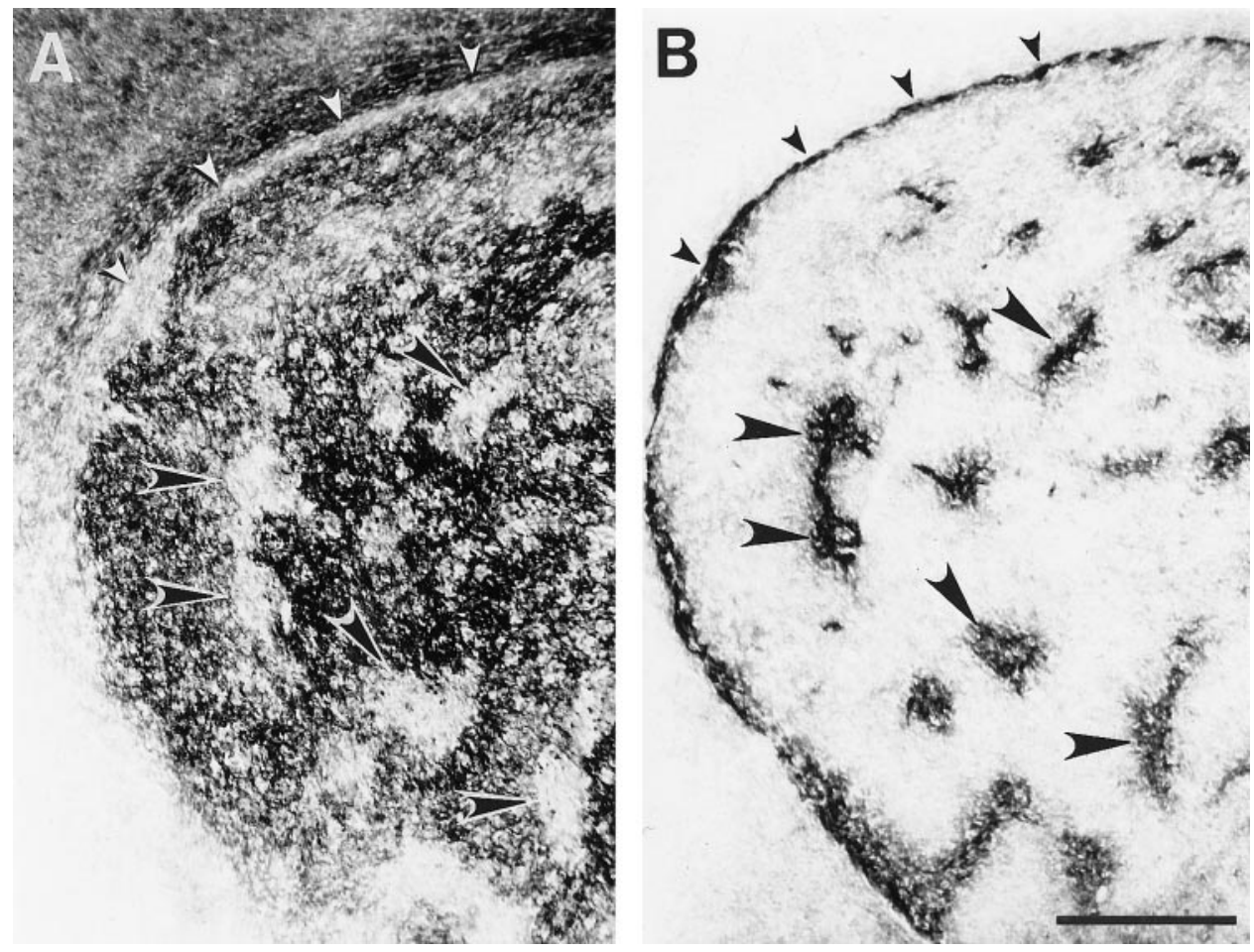

Figure 3. Adjacent coronal sections of a P6 striatum. $A$, Ephrin-A4-Fc binding is distributed in a mosaic pattern that contains striosomes lacking binding (large arrowheads). Binding also is absent in the subcallosal streak (small arrowheads). $B, \mu$-Opioid receptor immunohistochemistry in an adjacent section illustrates dense reactivity in areas that correspond to the striosomes (large arrowheads) and subcallosal streak (small arrowheads). Scale bar, $500 \mu \mathrm{m}$.

binding. Evaluation of the ephrin-A1 and ephrin-A4 binding pattern in a series of coronal sections through the striatum suggested that the patches lacking ligand binding formed finger-like interconnections within a three-dimensional matrix of cellular processes that bound these ligands. An additional prominent feature of this binding pattern was a noticeable lack of ligand binding along a thin streak of neuropil located immediately beneath the corpus callosum and external capsule (Figs. 2, 3A). This mosaic pattern of ephrin-A1 and ephrin-A4 binding appeared to delineate the matrix compartment of the striatum described in other studies (Herkenham and Pert, 1981; Graybiel, 1984; Nastuk and Graybiel, 1985; Gerfen et al., 1987; for review, see Gerfen, 1992; Heimer et al., 1995; Parent and Hazrati, 1995). In contrast, the binding of ephrin-A2-Fc, ephrin-A3-Fc, and ephrin-A5-Fc fusion proteins resulted in a noticeably different mosaic pattern (Fig. $1 B-D$ ). This mosaic pattern appeared very similar for these three ephrin-A ligands and consisted of prominent bands of neuropil that bound these ligands, separated by areas with very limited ligand binding. Ephrin-A2-Fc and ephrin-A5-Fc produced an identical binding pattern, whereas ephrin-A3-Fc exhibited weaker binding, although the distribution of areas demonstrating more extensive binding appeared to colocalize primarily with areas exhibiting the densest binding for ephrin-A2-Fc and ephrin-A5-Fc in adjacent sections (Fig. $1 B-D$ ). Bands of ligand binding were evident in coronal sections where they exhibited a dorsomedial-ventrolateral orientation. These bands extended within a longitudinal plane for considerable distances along the rostral-caudal axis of the striatum. Qualitative evaluation of the 

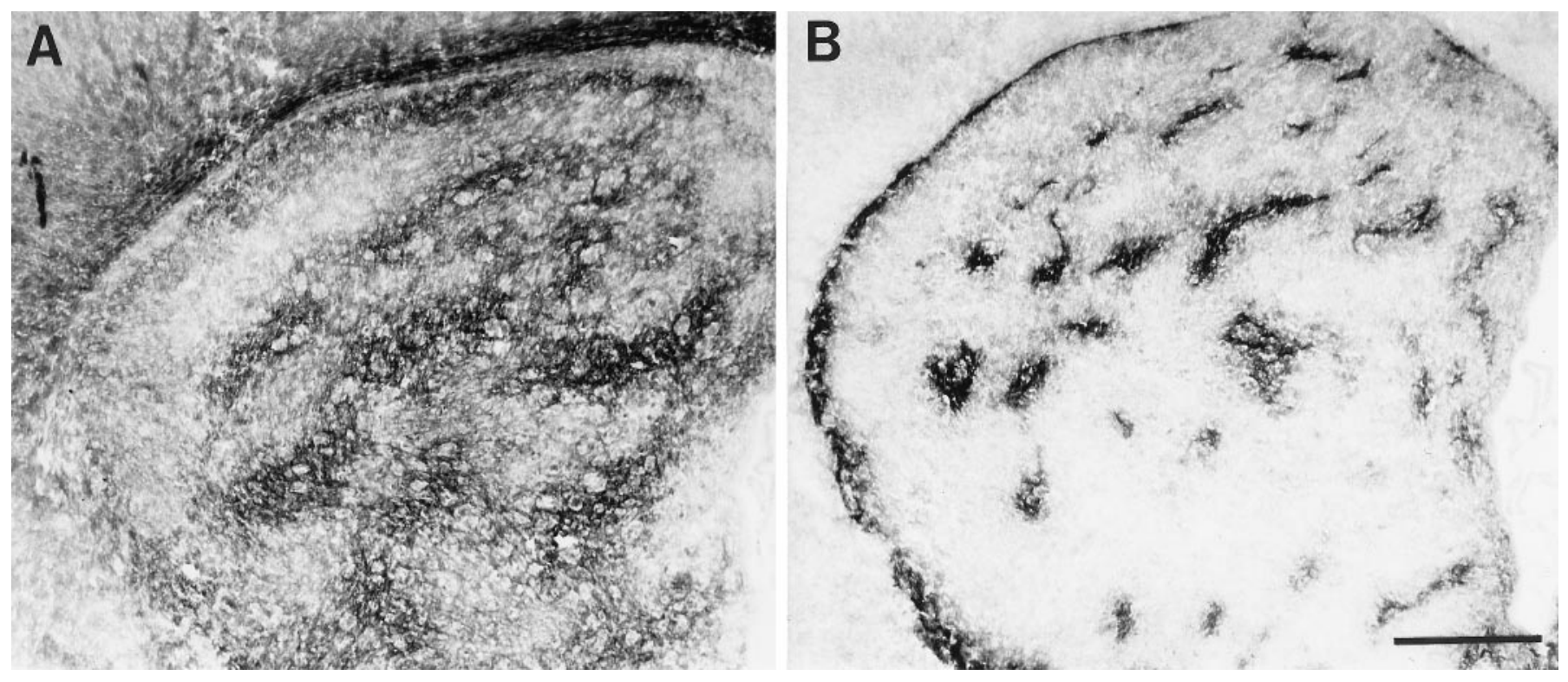

Figure 4. Adjacent coronal sections through the P6 striatum incubated with ephrin-A5-Fc fusion protein $(A)$ or antibody against the $\mu$-opioid receptor $(B)$. Ephrin-A5-Fc binding is distributed in a mosaic pattern that does not accurately compliment those regions of neuropil exhibiting $\mu$-opioid receptor immunohistochemistry. Scale bar, $500 \mu \mathrm{m}$.

Figure 5. Comparison of ephrinA4-Fc binding and EphA4 mRNA expression in P6 striatum. Adjacent coronal sections were incubated with ephrinA4-Fc fusion protein $(A)$ or processed for in situ hybridization for EphA4 mRNA ( $B)$. $A$, Bright-field micrograph showing the binding pattern of ephrinA4-Fc. B, Dark-field micrograph showing in situ hybridization of EphA4 mRNA. Asterisks indicate corresponding areas between the two adjacent sections that lack ephrin-A4-Fc binding and EphA4 message. $a$, Anterior commissure. Scale bar, $500 \mu \mathrm{m}$.
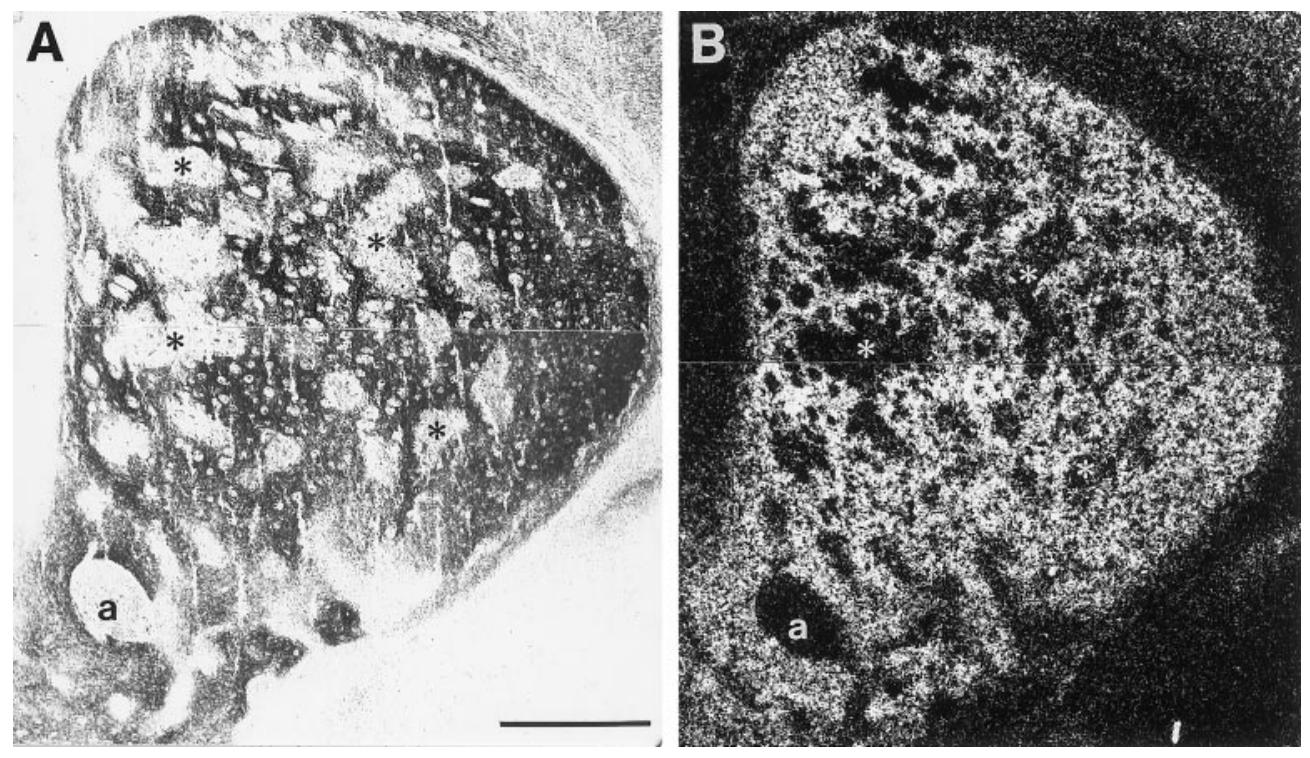

intensity of the immunohistochemical reaction used to visualize the binding of ephrin-A-Fc fusion proteins on fixed tissue sections suggested that the ephrin-A ligands exhibited different binding affinities. For example, ephrin-A4 and ephrin-A5 produce the greatest staining intensity, followed by ephrin-A2, ephrin-A1, and ephrin-A3. None of the ephrin-A-Fc fusion proteins bound to corticof ugal axons within the fascicles of the internal capsule that perforate the striatum.

\section{Ephrin-A1 and ephrin-A4 binding delineate the striatal matrix compartment}

To confirm that the mosaic pattern observed with ephrin-A1 and ephrin-A4 binding corresponded to the known anatomical striosome and matrix organization of the striatum, we incubated adjacent sections with ephrin-A1-Fc, ephrin-A4-Fc, or antibodies to the $\mu$-opioid receptor because this receptor provides a precise marker for the striosome compartment from $\mathrm{P} 4$ to adult
(Herkenham and Pert, 1981; Delfs et al., 1994; Mansour et al., 1994; Arvidsson et al., 1995; Wang et al., 1996). Evaluation of adjacent serial sections incubated with ephrin-A4-Fc or $\mu$-opioid receptor antibodies clearly indicated that ephrin-A4 bound to cells and cellular processes restricted to the matrix compartment and selectively avoided the $\mu$-opioid receptor-containing striosome patches (Fig. 3). To confirm further that the mosaic patterns observed for ephrin-A2-Fc, ephrin-A3-Fc, and ephrin-A5-Fc binding did not match the mosaic pattern for the $\mu$-opioid receptors, we incubated serial adjacent sections with ephrin-A5-Fc or $\mu$-opioid receptor antibodies (Fig. 4). Evaluation of this material indicated that there were large areas of neuropil devoid of ligand binding that surrounded areas exhibiting staining for $\mu$-opioid receptors. Comparison of serial sections incubated with ephrinA-Fc fusion proteins further indicated that those regions exhibiting binding with ephrin-A2, ephrin-A3, and ephrin-A5 ap- 

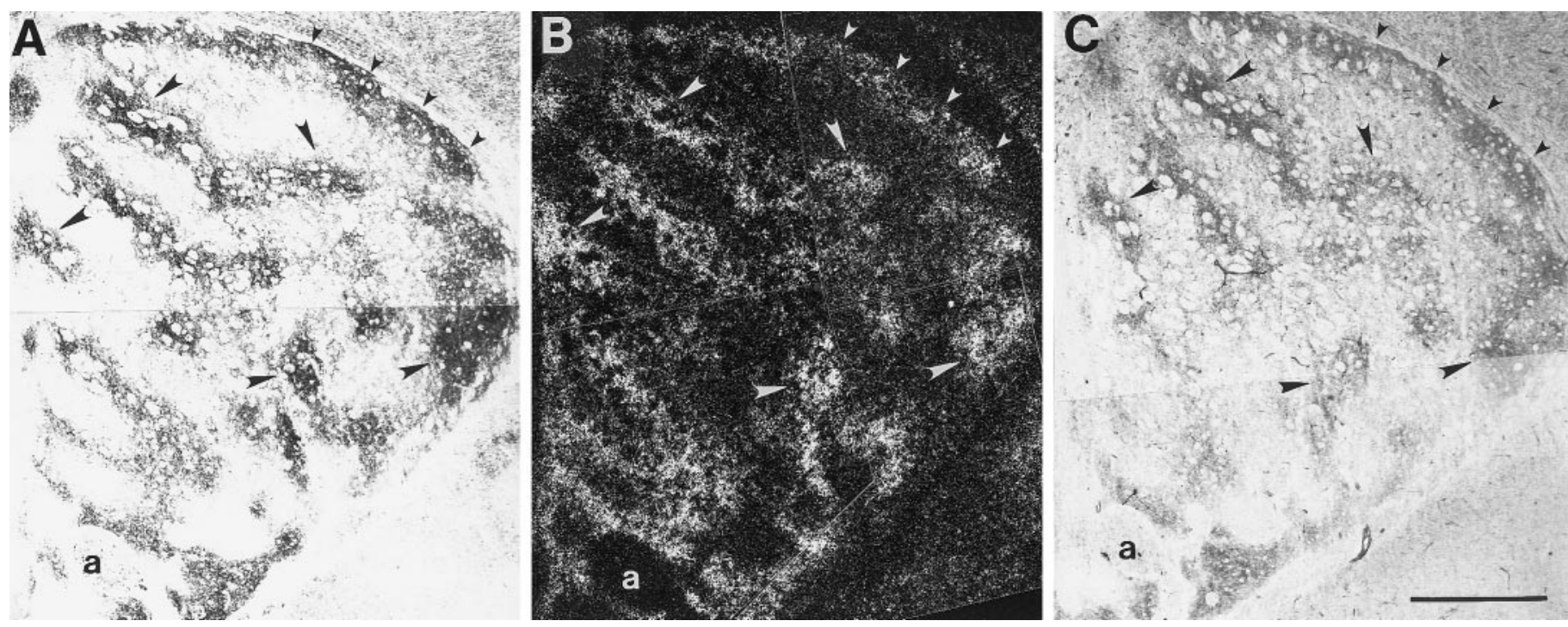

Figure 6. Comparison of ephrin-A5-Fc and ephrin-A2-Fc binding and EphA7 mRNA expression in P6 striatum. Adjacent coronal sections were incubated with ephrin-A5-Fc $(A)$ or ephrin-A2-Fc $(C)$ or processed for in situ hybridization of EphA7 mRNA $(B)$. $A, C$, Bright-field micrographs showing the binding patterns of ephrin-A5-Fc and ephrin-A2-Fc, respectively. $B$, Dark-field micrograph illustrating the in situ hybridization pattern for EphA7 mRNA. Corresponding areas of ligand binding and EphA7 mRNA expression are evident scattered within the striatal neuropil (large arrowheads) and within a large band of neuropil extending along the dorsolateral striatal border (small arrowheads). $a$, Anterior commissure. Scale bar, $500 \mu \mathrm{m}$.

peared to be located within areas that also bound ephrin-A4 (Fig. 1). These observations suggest that cells and cellular processes that bind ephrin-A2, ephrin-A3, and ephrin-A5 comprise a subset of the cell population that binds ephrin-A4.

\section{Ephrin-A-Fc binding mosaics overlap expression patterns for different EphA receptors}

To identify which EphA receptors were responsible for the observed ephrin-A-Fc binding patterns, we used in situ hybridization to examine the expression patterns of several EphA receptors that are reported to be expressed in the postnatal striatum (Maisonpierre et al., 1993; Mori et al., 1995a,b; Cassidy et al., 1996). Two receptors, EphA4 and EphA7, exhibited distinct and partially overlapping mosaic expression patterns in the postnatal striatum that resembled the mosaic binding patterns seen with the ephrin-A-Fc fusion proteins (Figs. 5, 6). To compare directly the patterns of receptor expression with patterns of ligand binding, serial adjacent sections through the striatum were either hybridized for EphA mRNA or incubated with the ephrin-A-Fc fusion proteins. Because ephrin-A2, ephrin-A4, and ephrin-A5 produced the most intense binding reactions, we compared the binding patterns of these ligands with the in situ expression patterns of EphA4 and EphA7 receptor mRNA. This comparison revealed that the two distinctive mosaic patterns of ephrin-A binding (i.e., ephrin-A1 and ephrin-A4 vs ephrin-A2 and ephrin-A5) exactly corresponded to the in situ mRNA patterns observed for EphA4 and EphA7. The mosaic pattern of EphA4 mRNA expression directly correlated with the pattern of ephrin-A4 binding to the matrix compartment (Fig. 5). The striosome compartment, which lacks ephrin-A4 binding as described above, also contained neurons that did not express EphA4 mRNA. Conversely, the pattern for EphA7 mRNA exactly matched the binding pattern of ephrin-A2 and ephrin-A5 (Fig. 6). Message for neither receptor was detected in glial cells associated with the internal capsule fibers that perforate the striatum, as expected from the lack of ephrin-A ligand binding to these regions.

\section{Differential binding of ephrin-A-Fc proteins to endogenous EphA receptors in the striatum}

The finding that different members of the ephrin-A subfamily of ligands display strikingly different binding patterns in the striatum and that these patterns overlap the expression patterns of EphA4 and EphA7 receptors suggests that the binding of ephrin-A ligands to endogenous EphA receptors may be selective and specific. To determine whether ephrin-A ligands can differentially recognize EphA4 and EphA7 receptors in the postnatal striatum, we performed ligand-receptor binding assays. Protein lysates from P6 striatum were incubated with each of the five ephrin$\mathrm{A}-\mathrm{Fc}$ fusion proteins, and the precipitated EphA4 and EphA7 receptors were identified on the resulting Western blots by probing with affinity-purified antibodies specific for EphA4 or EphA7 (Janis and Kromer, 1997). Results from this experiment demonstrated that both ephrin-A1 and ephrin-A4 (but not ephrin-A2, ephrin-A3, or ephrin-A5) bound and precipitated EphA4 receptors in the striatum (Fig. $7 A$ ). In contrast, no binding of ephrin-A1 or ephrin-A4 to EphA7 receptors was detected although EphA7 receptor protein was precipitated by ephrin-A2, ephrin-A3, and ephrin-A5 fusion proteins (Fig. 7B). These data correlate with the histological observations that ephrin-A2 and ephrin-A5 bind specifically to areas of the striatum containing cells expressing EphA7 receptors, whereas ephrin-A1 and ephrin-A4 bind selectively to areas expressing EphA4 mRNA.

\section{DISCUSSION}

Several results from the present study are particularly significant with respect to our current understanding of the role ephrins and Eph RTKs play in the organization of subregions in the CNS. First, our ligand-receptor binding assays indicate that members of the ephrin-A subfamily exhibit selectivity in their binding to endogenous EphA4 and EphA7 receptors found in neural tissue. Second, the five members of the ephrin-A ligand family exhibit two distinct mosaic binding patterns to EphA receptors present in striatal tissue sections. Third, EphA4 and EphA7 transcripts 


\section{A. EphA4}

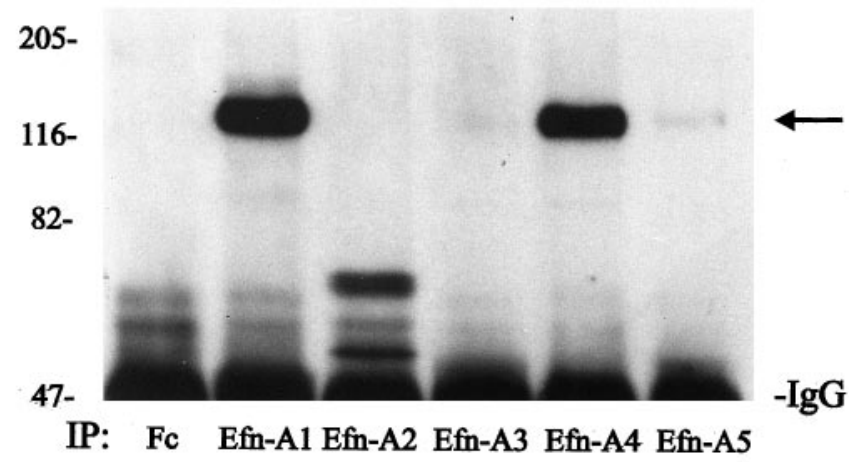

\section{B. EphA7}

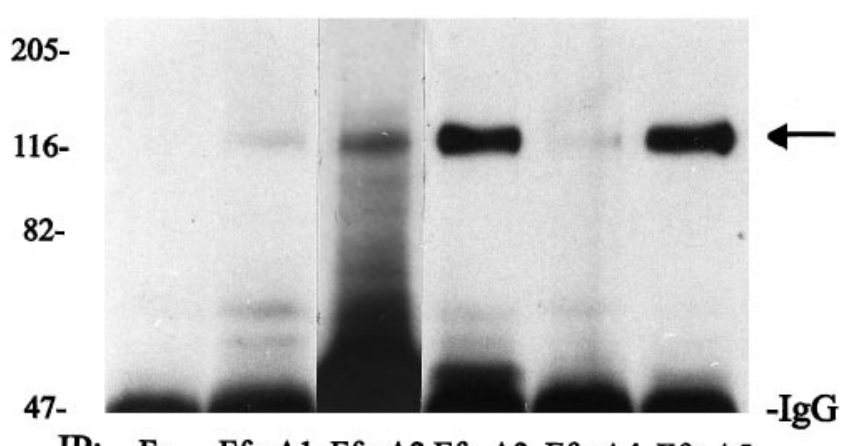

IP: Fc Efn-A1 Efn-A2 Efn-A3 Efn-A4 Efn-A5

Figure 7. Ephrin-A ligand-receptor binding assay. Protein lysates from P6 striatum were precipitated either with control $\mathrm{Fc}-\mathrm{IgG}$ fusion protein $(F c)$ or with one of five different ephrin-A-Fc fusion proteins (ephrin-A1, ephrin-A2, ephrin-A3, ephrin-A4, or ephrin-A5), and the resulting Western blot was probed with antibodies specific for either EphA4 $(A)$ or EphA7 $(B) . A$, Only ephrin-A1 $(E f n-A 1)$ and ephrin-A4 $(E f n-A 4)$ bound and precipitated EphA4. B, EphA7 was precipitated by ephrin-A2 (Efn$A 2)$, ephrin-A3 (Efn-A3), and ephrin-A5 $(E f n-A 5)$ but not by ephrin-A1 and ephrin-A4. IP, Immunoprecipitating ligands. Numbers on left indicate positions of molecular weight markers in kilodaltons.

exhibit different mosaic patterns in the striatum that correlate with the two different binding patterns observed for the ephrinA-Fc fusion proteins. Fourth, the mosaic pattern for ephrin-A1 and ephrin-A4 binding and the expression of EphA4 RTKs directly correlate with the matrix compartment of the striatum. These observations support several hypotheses regarding the possible role of EphA receptors and class A ephrins in striatal organization.

\section{Ephrin-A ligands exhibit binding specificity for EphA4 and EphA7 receptors in vivo}

Our data from the ligand binding assays indicate that ephrinA1-Fc and ephrin-A4-Fc fusion proteins exhibit strong selectivity in their ability to bind and precipitate neuronal EphA4 receptors isolated from the postnatal striatum. In contrast, ephrin-A2, ephrin-A3, and ephrin-A5 exhibit strong preferential binding and precipitation of endogenous EphA7 receptors. These results are not completely consistent with previously reported ligand-receptor binding affinities, which were based on results obtained from in vitro expression systems. These previous studies reported that all ephrin-A ligands bind to both EphA4 and EphA7 receptors, although there is a hierarchy in binding affin- ities (Cheng and Flanagan, 1994; Davis et al., 1994; Gale et al., 1996b; Monschau et al., 1997; for review, see Gale and Yancopoulos, 1997). The data from our ligand binding assays indicate that there is more restricted binding of ephrins to endogenous neuronal EphA receptors. For example, the in vitro binding data for EphA7 predict that ephrin-A2, ephrin-A3, and ephrin-A5 would have the greatest affinity for EphA7 receptors, with less binding expected for ephrin-A1 and ephrin-A4. Our results indicate that there is greater specificity of ligand binding to the native EphA7 receptors because ephrin-A1 and ephrin-A4 do not exhibit detectable binding to EphA7 in our assay. Our results for the EphA4 receptor are consistent with the in vitro binding data with the exception of data on ephrin-A5. Although in vitro results indicate that the binding affinity of ephrin-A5 to EphA4 should be equivalent to that obtained for ephrin-A1 and ephrin-A4, we did not detect binding of ephrin-A5 to this receptor. Ephrin-A2 and ephrin-A3 also lack detectable binding to this receptor.

One possible explanation for the difference in binding affinity observed between our experiments with native EphA receptors from neural tissue versus experiments using in vitro expression systems could be attributable to differences in the posttranslational modifications of EphA receptors that occur in neurons versus the COS cells that produced the receptor-Fc fusion proteins used in the in vitro studies (Davis et al., 1994; Gale et al., 1996b; Monschau et al., 1997). An additional methodological difference between the in vitro binding studies and the present ligand binding procedure was the use of lysed cell membranes in our binding competition assays. Thus, the in vitro studies evaluated binding of a single soluble EphA-Fc protein to a single type of ephrin-A ligand on the surface of intact COS cells, whereas our tissue lysates contained multiple solubilized EphA receptors, which were free to compete for binding with a single ephrin-A-Fc protein. The results from our assays clearly demonstrate that there is selectivity in the binding of ephrin-A ligands to neuronal EphA RTKs because EphA4 and EphA7 receptors are differentially precipitated from the same tissue lysate by different ephrinA-Fc fusion proteins. Additional support for the validity of our protein data for ligand-receptor binding specificity is provided by our anatomical studies that correlated the localization of ephrin-A binding sites with in situ hybridization results for the distribution of EphA4 and EphA7 mRNA in the striatum as discussed below.

\section{Expression patterns for specific EphA receptors match the differential binding for ephrin-A ligands}

Our ephrin-A-Fc binding procedure for the anatomical localization of EphA receptors has been adapted from procedures used in several previous studies to localize EphA receptors or ephrin-A ligands in embryo whole-mounts (Cheng and Flanagan, 1994; Cheng et al., 1995; Flenniken et al., 1996; Gale et al., 1996b). In these studies EphA and ephrin-A could only be localized at the gross level, and binding was restricted to more superficial structures because of limitations with penetration of the fusion proteins into the whole embryos. However, even with these limitations, some differences in binding between the ephrin-A ligands have been noted. For example, ephrin-A4 binds to early-forming somites, but ephrin-A3 and ephrin-A5 do not; ephrin-A1, but not ephrin-A2, exhibits binding to the limb buds (Flenniken et al., 1996; Gale et al., 1996b). These findings are the first evidence that EphA receptors may exhibit more selective ligand binding in vivo than would be predicted from the in vitro binding data. Because our ephrin-A-Fc binding was performed on tissue sections rather 
than on whole embryos, the sensitivity and anatomical resolution of our procedure permit us to delineate ligand binding sites at the cellular level more clearly and to correlate this ephrin-A-Fc binding with the cellular localization of EphA4 and EphA7 transcripts in adjacent sections. A similar technique was used to demonstrate that alkaline phosphatase-tagged EphA5 exhibits selective binding to regions of the CNS that express message for ephrin-A2, ephrin-A3, and ephrin-A5 (Zhang et al., 1996). Thus, our results strongly suggest that subgroups of ephrin-A ligands are able to associate selectively with endogenous EphA4 and EphA7 receptors present on cells in the striatum. In particular, there is a strong correlation between the cellular distribution of EphA7 receptor message in the striatum and binding sites for ephrin-A2, ephrin-A3, and ephrin-A5. Likewise, binding sites for ephrin-A1 and ephrin-A4 completely overlapped the distribution of cells expressing mRNA for EphA4 but not EphA7. These anatomical results are in complete agreement with the biochemical data for the specificity of ephrin-A/EphA binding in tissue lysates from the striatum.

An additional important aspect of this study is the correlation of ephrin-A binding and EphA expression with the known cellular compartmentation of the striatum. Our combined $\mu$-opioid receptor immunohistochemical staining results and the in situ hybridization data indicate that cells in the matrix compartment but not the striosomes express both EphA4 and EphA7. Thus, either a subset of EphA4-expressing neurons also contains EphA7 receptors, or there is a separate subpopulation of matrix neurons that only express EphA7 receptors. Previous studies have demonstrated that neurons within the matrix compartment can be subdivided into cellular modules that receive selective afferents from restricted regions of the thalamus and cortex and, in turn, send efferent projections to different target nuclei of the striatum (Goldman and Nauta, 1977; Goldman-Rakic, 1981; Malach and Graybiel, 1986; Desban et al., 1989, 1995; Jimenez-Castellanos and Graybiel, 1989; Berendse and Groenewegen, 1990; GimenezAmaya and Graybiel, 1991; Eblen and Graybiel, 1995; Kincaid and Wilson, 1996). One mechanism that might account for this further segregation of matrix neurons could involve interactions between ephrin-A ligands and EphA7 receptors on a subset of matrix neurons that are segregating into these modules.

\section{Ephrin-A1 and/or ephrin-A4 and EphA4 are associated with the striosome and matrix organization of the striatum}

Previous studies indicate that EphA4 transcripts were present in the postnatal striatum (Mori et al., 1995a) and that EphA4 protein was reported to be distributed in a matrix-like pattern in the adult striatum on the basis of its immunohistochemical localization (Martone et al., 1997). The present data extend these previous findings and strongly implicate ephrin-A1 and/or ephrin-A4, in conjunction with EphA4 receptors, in the segregation of matrix neurons from those in the striosome compartment. This conclusion is based on several observations. First, there is selective binding of ephrin-A1 and ephrin-A4 to cellular processes within the striatal matrix but not to processes within the $\mu$-opioid receptor-containing striosomes. Second, ephrin-A1 and ephrin-A4 selectively precipitate EphA4, but not EphA7, from striatal protein lysates. Third, the distribution of cells expressing EphA4 mRNA exactly correlates with the distribution of matrix neurons, whereas cells within the striosomes lack detectable signal for EphA4.
The experiments in the present study cannot completely eliminate the possibility that EphA receptors other than EphA4 may be involved in some aspects of striosome and/or matrix formation. Several observations, however, indicate that EphA1, EphA2, EphA3, EphA5, and EphA7 receptors probably are not directly associated with striosome and/or matrix formation. Transcripts for EphA1, EphA2, and EphA5 receptors are not expressed in the postnatal striatum (Becker et al., 1994; Ruiz and Roberston, 1994; Zhang et al., 1997; for review, see Zhou, 1998), and EphA3 protein levels rapidly decrease after P0 (Janis and Kromer, 1997). Moreover, the distribution of cells expressing EphA7 transcripts does not directly correlate with the boundaries between the striosome and matrix compartments. However, message for EphA6 and EphA8 is present in the postnatal striatum (Maisonpierre et al., 1993) (R. M. Cassidy and L. F. Kromer, unpublished observations), and it is possible that these two receptors could be expressed selectively by striosome or matrix neurons. At present we have been unsuccessful in determining whether EphA6 and EphA8 receptor protein is present in the striatum using commercially available antibodies (Santa Cruz Biotechnology, Santa Cruz, CA). Thus, we are currently conducting in situ hybridization experiments to determine whether either of these receptors exhibits a mosaic expression pattern that could correlate with striosome and/or matrix organization.

An important question that remains to be addressed is the distribution of ephrin-A ligands within the striatum. Because ligand activation of EphA receptors is reported to produce repulsive effects on cellular process outgrowth (Drescher et al., 1995; Monschau et al., 1997; for review, see also Harris and Holt, 1995; Tessier-Lavigne, 1995; Zisch and Pasquale, 1997), a particular ephrin-A ligand and its cognate EphA receptor should be localized within juxtaposed cellular compartments in the striatum, as has been observed for the developing rhombomeres (GilardiHebenstreit et al., 1992; Nieto et al., 1992; Becker et al., 1994; Henkemeyer et al., 1994; Winning and Sargent, 1994; Ellis et al., 1995; Flenniken et al., 1996; Gale et al., 1996a; Taneja et al., 1996; for review, see Flanagan and Vanderhaeghen, 1998). Because our results strongly implicate ephrin-A1 and/or ephrin-A4 in striosome and matrix segregation, these ligands should be expressed by the striosome neurons and distributed on their cellular processes or should be present on early-arriving afferents that initially innervate the striosomes. Thus, the presence of ephrin-A1 and/or ephrin-A4 on cellular processes of neurons in the developing striosomes or on the afferents to the striosome neurons would result in the exclusion of matrix neurons and their developing dendrites from these regions. Further experiments are in progress to address these questions directly.

\section{REFERENCES}

Albin RL, Young AB, Penney JB (1989) The functional anatomy of basal ganglia disorders. Trends Neurosci 12:366-375.

Alheid GF, Heimer L (1988) New perspectives in basal forebrain organization of special relevance for neuropsychiatric disorders: the striatopallidal, amygdaloid and corticopetal components of substantia innominata. Neuroscience 27:1-39.

Arnauld E, Arsaut J, Tafani JA, Demotes-Mainard J (1995) Dopaminergic control of gene transcription during striatal ontogeny: c-fos induction by $\mathrm{D} 1$ receptor activation in the developing striosomes. Mol Brain Res 30:223-232.

Arvidsson U, Riedl M, Chakrabarti S, Lee J-H, Nakano AH, Dado RJ, Loh HH, Law P-Y, Wessendorf MW, Elde R (1995) Distribution and targeting of a $\mu$-opioid receptor (MOR1) in brain and spinal cord. J Neurosci 15:3328-3341.

Becker N, Seitanidou T, Murphy P, Mattei MG, Topilko P, Nieto MA, Wilkinson DG, Charnay P, Gilardi-Hebenstreit P (1994) Several re- 
ceptor tyrosine kinase genes of the Eph family are segmentally expressed in the developing hindbrain. Mech Dev 47:3-17.

Berendse HW, Groenewegen HJ (1990) Organization of the thalamostriatal projections in the rat, with special emphasis on the ventral striatum. J Comp Neurol 299:187-228.

Bergemann AD, Cheng HJ, Brambilla R, Klein R, Flanagan JG (1995) ELF-2, a new member of the Eph ligand family, is segmentally expressed in mouse embryos in the region of the hindbrain and newly forming somites. Mol Cell Biol 15:4921-4929.

Bishop GA, Chang HT, Kitai ST (1982) Morphological and physiological properties of neostriatal neurons: an intracellular horseradish peroxidase study in the rat. Neuroscience 7:179-191.

Bruckner K, Pasquale EB, Klein R (1997) Tyrosine phosphorylation of transmembrane ligands for Eph receptors. Science 275:1640-1643.

Carlsson M, Carlsson A (1990) Interactions between glutamatergic and monoaminergic systems within the basal ganglia-implication for schizophrenia and Parkinson's disease. Trends Neurosci 13:272-276.

Cassidy RM, Holst PL, Fox GM, Kromer LF (1996) Rek-4 receptor expression is developmentally regulated in the rodent forebrain. Soc Neurosci Abstr 22:1478.

Cheng H, Flanagan JG (1994) Identification and cloning of ELF-1, a developmentally expressed ligand for the Mek4 and Sek receptor tyrosine kinases. Cell 79:157-168.

Cheng HJ, Nakamoto M, Bergemann AD, Flanagan JG (1995) Complementary gradients in expression and binding of ELF-1 and Mek4 in development of the topographic retinotectal projection map. Cell 82:371-381.

Ciossek T, Ullrich A (1997) Identification of Elf-1 and B61 as high affinity ligands for the receptor tyrosine kinase MDK1. Oncogene 14:35-43.

Davenport RW, Thies E, Zhou R, Nelson PG (1998) Cellular localization of ephrin-A2, ephrin-A5, and other functional guidance cues underlies retinotopic development across species. J Neurosci 18:975-986.

Davis S, Gale NW, Aldrich TH, Maisonpierre PC, Lhotak V, Pawson T, Goldfarb M, Yancopoulos GD (1994) Ligands for EPH-related receptor tyrosine kinases that require membrane attachment or clustering for activity. Science 266:816-819.

Delfs JM, Kong H, Mestek A, Chen Y, Yu L, Reisine T, Chesselet MF (1994) Expression of mu opioid receptor mRNA in rat brain: an in situ hybridization study at the single cell level. J Comp Neurol 345:46-68.

Desban M, Gauchy C, Kemel ML, Besson MJ, Glowinski J (1989) Three-dimensional organization of the striosomal compartment and patchy distribution of striatonigral projections in the matrix of the cat caudate nucleus. Neuroscience 29:551-566.

Desban M, Gauchy C, Glowinski J, Kemel ML (1995) Heterogeneous topographical distribution of the striatonigral and striatopallidal neurons in the matrix compartment of the cat caudate nucleus. J Comp Neurol 352:117-133.

Drescher U, Kremoser C, Handwerker C, Loschinger J, Noda M, Bonhoeffer F (1995) In vitro guidance of retinal ganglion cell axons by RAGS, a $25 \mathrm{kDa}$ tectal protein related to ligands for $\mathrm{Eph}$ receptor tyrosine kinases. Cell 82:359-370.

Durbin L, Brennan C, Shiomi K, Cooke J, Barrios A, Shanmugalingam S, Guthrie B, Lindberg R, Holder N (1998) Eph signaling is required for segmentation and differentiation of the somites. Genes Dev 12:3096-3109.

Eblen F, Graybiel AM (1995) Highly restricted origin of prefrontal cortical inputs to striosomes in the macaque monkey. J Neurosci 15:5999-6013

Ellis C, Kasmi F, Ganju P, Walls E, Panayotou G, Reith AD (1996) A juxtamembrane autophosphorylation site in the Eph family receptor tyrosine kinase, Sek, mediates high affinity interaction with p59fyn. Oncogene 12:1727-1736.

Ellis J, Liu Q, Breitman M, Jenkins NA, Gilbert DJ, Copeland NG, Tempest HV, Warren S, Muir E, Schilling H, Fletcher FA, Ziegler SF, Rogers JH (1995) Embryo brain kinase: a novel gene of the eph/elk receptor tyrosine kinase family. Mech Dev 52:319-341.

Fishell G, van der Kooy D (1987) Pattern formation in the striatum: developmental changes in the distribution of striatonigral neurons. J Neurosci 7:1969-1978.

Flanagan JG, Vanderhaeghen P (1998) The ephrins and Eph receptors in neural development. Annu Rev Neurosci 21:309-345.

Flenniken AM, Gale NW, Yancopoulos GD, Wilkinson DG (1996) Distinct and overlapping expression patterns of ligands for Eph-related receptor tyrosine kinases during mouse embryogenesis. Dev Biol 179:382-401.

Fox GM, Holst PL, Chute HT, Lindberg RA, Janssen AM, Basu R, Welcher AA (1995) cDNA cloning and tissue distribution of five human Eph-like receptor protein-tyrosine kinases. Oncogene 10:897-905.

Friedman GC, O'Leary D (1996) Eph receptor tyrosine kinases and their ligands in neural development. Curr Opin Neurobiol 6:127-133.

Fryer RH, Kaplan DR, Feinstein SC, Radeke MJ, Grayson DR, Kromer LF (1996) Developmental and mature expression of full-length and truncated trkB receptors in the rat forebrain. J Comp Neurol 374:21-40.

Gale MW, Yancopoulos GD (1997) Ephrins and their receptors: a repulsive topic? Cell Tissue Res 290:227-241.

Gale NW, Flenniken A, Compton DC, Jenkins N, Copeland NG, Gilbert DJ, Davis S, Wilkinson DG, Yancopoulos GD (1996a) Elk-L3, a novel transmembrane ligand for the Eph family of receptor tyrosine kinases, expressed in embryonic floor plate, roof plate and hindbrain segments. Oncogene 13:1343-1352.

Gale NW, Holland SJ, Valenzuela DM, Flenniken A, Pan L, Ryan TE, Henkemeyer M, Strebhardt K, Hirai H, Wilkinson DG, Pawson T, Davis S, Yancopoulos GD (1996b) Eph receptors and ligands comprise two major specificity subclasses and are reciprocally compartmentalized during embryogenesis. Neuron 17:9-19.

Gao PP, Zhang JH, Yokoyama M, Racey B, Dreyfus CF, Black IB, Zhou $\mathrm{R}$ (1996) Regulation of topographic projection in the brain: Elf- 1 in the hippocamposeptal system. Proc Natl Acad Sci USA 93:11161-11166. Gao PP, Yue Y, Zhang JH, Cerretti DP, Levitt P, Zhou R (1998) Regulation of thalamic neurite outgrowth by the Eph ligand ephrin-A5: implications in the development of thalamocortical projections. Proc Natl Acad Sci USA 95:5329-5334.

Gerfen CR (1984) The neostriatal mosaic: compartmentalization of corticostriatal input and striatonigral output systems. Nature 311:461-464.

Gerfen CR (1989) The neostriatal mosaic: striatal patch-matrix organization is related to cortical lamination. Science 246:385-388.

Gerfen CR (1992) The neostriatal mosaic: multiple levels of compartmental organization in the basal ganglia. Annu Rev Neurosci $15: 285-320$

Gerfen CR, Herkenham M, Thibault J (1987) The neostriatal mosaic. II. Patch- and matrix-directed mesostriatal dopaminergic and nondopaminergic systems. J Neurosci 7:3915-3934.

Gilardi-Hebenstreit P, Nieto MA, Frain M, Mattei M-G, Chestier A, Wilkinson DG, Charnay P (1992) An Eph-related receptor protein tryosine kinase gene segmentally expressed in the developing mouse hindbrain. Oncogene 7:2499-2506.

Gimenez-Amaya JM, Graybiel AM (1991) Modular organization of projection neurons in the matrix compartment of the primate striatum. J Neurosci 11:779-791.

Goldman PS, Nauta WJ (1977) An intricately patterned prefrontocaudate projection in the rhesus monkey. J Comp Neurol 72:369-386.

Goldman-Rakic PS (1981) Prenatal formation of cortical input and development of cytoarchitectonic compartments in the neostriatum of the rhesus monkey. J Neurosci 1:721-735.

Graybiel AM (1984) Correspondence between the dopamine islands and striosomes of the mammalian striatum. Neuroscience 13:1157-1187.

Harris WA, Holt CE (1995) From tags to RAGS: chemoaffinity finally has receptors and ligands. Neuron 15:241-244.

Heimer L, Zahm DS, Alheid GF (1995) Basal ganglia. In: The rat nervous system (Paxinos G, ed), pp 579-628. San Diego: Academic.

Henkemeyer M, Marengere LEM, McGlade J, Olivier JP, Conlon RA, Holmyard DP, Letwin K, Pawson T (1994) Immunolocalization of the Nuk receptor tyrosine kinase suggests roles in segmental patterning of the brain and axonogenesis. Oncogene 9:1001-1014.

Herkenham M, Pert CB (1981) Mosaic distribution of opiate receptors, parafascicular projections and acetylcholinesterase in rat striatum. Nature 291:415-418.

Holland SJ, Gale NW, Mbamalu G, Yancopoulos GD, Henkemeyer M, Pawson T (1996) Bidirectional signalling through the EPH-family receptor Nuk and its transmembrane ligands. Nature 383:722-725.

Holland SJ, Gale NW, Gish GD, Roth RA, Songyang Z, Cantley LC, Henkemeyer M, Yancopoulos GD, Pawson T (1997) Juxtamembrane tyrosine residues couple the Eph family receptor EphB2/Nuk to specific SH2 domain proteins in neuronal cells. EMBO J 16:3877-3888.

Janis LS, Kromer LF (1997) Differential expression of Mek-4, an EphA3 tyrosine kinase receptor, in the developing rat CNS. Soc Neurosci Abstr 23:324. 
Jimenez-Castellanos J, Graybiel AM (1989) Compartmental origins of striatal efferent projections in the cat. Neuroscience 32:297-321.

Kincaid AE, Wilson CJ (1996) Corticostriatal innervation of the patch and matrix in the rat neostriatum. J Comp Neurol 374:578-592.

Krull CE, Lansford R, Gale NW, Collazo A, Marcelle C, Yancopoulos GD, Fraser SE, Bronner-Fraser M (1997) Interactions of Eph-related receptors and ligands confer rostrocaudal pattern to trunk neural crest migration. Curr Biol 7:571-580.

Lanca AJ, Boyd S, Kolb BE, van der Kooy D (1986) The development of a patchy organization of the rat striatum. Dev Brain Res 27:1-10.

Loizou LA (1972) The postnatal ontogeny of monoamine-containing neurones in the central nervous system of the albino rat. Brain Res 40:395-418.

Maisonpierre PC, Barrequeta NX, Yancopoulos GD (1993) Ehk-1 and Ehk-2: two novel members of the Eph receptor-like tyrosine kinase family with distinctive structures and neuronal expression. Oncogene 8:3277-3288.

Malach R, Graybiel AM (1986) Mosaic architecture of the somatic sensory-recipient sector of the cat's striatum. J Neurosci 6:3436-3458.

Mansour A, Fox CA, Thompson RC, Akil H, Watson SJ (1994) $\mu$-Opioid receptor mRNA expression in the rat CNS: comparison to $\mu$-receptor binding. Brain Res 643:245-265.

Marsden CD (1981) The basal ganglia and the control of movement: motor activity and the outputs of the basal ganglia. Trends Neurosci $4: 124-125$.

Martone ME, Holash JA, Bayardo A, Pasquale EB, Ellisman MH (1997) Immunolocalization of the receptor tyrosine kinase EphA4 in the adult rat central nervous system. Brain Res 771:238-250.

Meima L, Kljavin IJ, Moran P, Shih A, Winslow JW, Caras IW (1997) AL-1-induced growth cone collapse of rat cortical neurons is correlated with Rek7 expression and rearrangement of actin cytoskeleton. Eur J Neurosci 9:177-188.

Monschau B, Kremoser C, Ohta K, Tanaka H, Kaneko T, Yamada T, Handwerker C, Hornberger MR, Loschinger J, Pasquale EB, Siever DA, Verderame MF, Muller BK, Bonhoeffer F, Drescher U (1997) Shared and distinct functions of RAGS and ELF-1 in guiding retinal axons. EMBO J 16:1258-1267.

Mori T, Wanaka A, Taguchi A, Matsumoto K, Tohyama M (1995a) Differential expressions of the eph family of receptor tyrosine kinase genes (sek, elk, eck) in the developing nervous system of the mouse. Mol Brain Res 29:325-335.

Mori T, Wanaka A, Taguchi A, Matsumoto K, Tohyama M (1995b) Localization of novel receptor tyrosine kinase genes of the eph family, MDK1 and its splicing variant, in the developing mouse nervous system. Mol Brain Res 34:154-160.

Murrin LC, Ferrer JR (1984) Ontogeny of the rat striatum: correspondence of dopamine terminals, opiate receptors and acetylcholinesterase. Neurosci Lett 47:155-160.

Murrin LC, Zeng WY (1989) Dopamine D1 receptor development in the rat striatum: early localization in striosomes. Brain Res 480:170-177.

Murrin LC, Zeng WY (1990) Ontogeny of dopamine D1 receptors in rat forebrain: a quantitative autoradiographic study. Dev Brain Res 57:7-13.

Nastuk MA, Graybiel AM (1985) Patterns of muscarinic cholinergic binding in the striatum and their relation to dopamine islands and striosomes. J Comp Neurol 237:176-194.

Nastuk MA, Graybiel AM (1988) Autoradiographic localization and biochemical characteristics of M1 and M2 muscarinic binding sites in the striatum of the cat, monkey, and human. J Neurosci 8:1052-1062.

Nieto MA, Gilardi-Hebenstreit P, Charnay P, Wilkinson DG (1992) A receptor protein tryosine kinase implicated in the segmental patterning of the hindbrain and mesoderm. Development 116:1137-1150.

Olson L, Seiger A, Fuxe K (1972) Heterogeneity of striatal and limbic dopamine innervation: highly fluorescent islands in developing and adult rats. Brain Res 44:283-288.
Parent A, Hazrati L-N (1995) Functional anatomy of the basal ganglia. I. The cortico-basal ganglia-cortical loop. Brain Res Rev 20:91-127.

Park S, Sanchez MP (1997) The Eek receptor, a member of the Eph family of tyrosine protein kinases, can be activated by three different Eph family ligands. Oncogene 14:533-542.

Penney Jr JB, Young AB (1993) Speculation on the functional anatomy of basal ganglia disorders. Annu Rev Neurosci 6:73-94.

Penny GR, Wilson CJ, Kitai ST (1988) Relationship of the axonal and dendritic geometry of spiny projection neurons to the compartmental organization of the neostriatum. J Comp Neurol 269:275-289.

Ruiz JC, Roberston EJ (1994) The expression of the receptor-protein tyrosine kinase gene, eck, is highly restricted during early mouse development. Mech Dev 46:87-100.

Schoen SW, Graybiel AM (1992) 5'-Nucleotidase: a new marker for striosomal organization in the rat caudoputamen. J Comp Neurol 322:566-576.

Taneja R, Thisse B, Rijli FM, Thisse C, Bouillet P, Dolle P, Chambon P (1996) The expression pattern of the mouse receptor tyrosine kinase gene MDK1 is conserved through evolution and requires Hoxa-2 for rhombomere-specific expression in mouse embryos. Dev Biol 177:397-412.

Tessier-Lavigne M (1995) Eph receptor tyrosine kinases, axon repulsion, and the development of topographic maps. Cell 82:345-348.

van der Kooy D, Fishell G (1987) Neuronal birthdate underlies the development of striatal compartments. Brain Res 401:155-161.

Voorn P, Kalsbeek A, Jorritsma-Byham B, Groenewegen HJ (1988) The pre- and postnatal development of the dopaminergic cell groups in the ventral mesencephalon and the dopaminergic innervation of the striatum of the rat. Neuroscience 25:857-887.

Walker RH, Arbuthnott GW, Baughman RW, Graybiel AM (1993) Dendritic domains of medium spiny neurons in the primate striatum: relationships to striosomal borders. J Comp Neurol 337:614-628.

Wang H, Moriwaki A, Wang JB, Uhl GR, Pickel VM (1996) Ultrastructural immunocytochemical localization of $\mu$-opioid receptors and leu ${ }^{5}$ enkephalin in the patch compartment of the rat caudate-putamen nucleus. J Comp Neurol 375:659-674.

Wang HU, Anderson DJ (1997) Eph family transmembrane ligands can mediate repulsive guidance of trunk neural crest migration and motor axon outgrowth. Neuron 18:383-396.

Wilson CJ, Groves PM (1980) Fine structure and synaptic connections of the common spiny neuron of the rat neostriatum: a study employing intracellular inject of horseradish peroxidase. J Comp Neurol 194:599-615.

Winning RS, Sargent TD (1994) Pagliaccio, a member of the Eph family of receptor tyrosine kinase genes, has localized expression in a subset of neural crest and neural tissues in Xenopus laevis embryos. Mech Dev 46:219-229.

Xu Q, Alldus G, Holder N, Wilkinson DG (1995) Expression of truncated Sek-1 receptor tyrosine kinase disrupts the segmental restriction of gene expression in the Xenopus and zebrafish hindbrain. Development 121:4005-4016.

Zhang J, Pimenta AF, Levitt P, Zhou R (1997) Dynamic expression suggests multiple roles of the eph family receptor brain-specific kinase (Bsk) during mouse neurogenesis. Mol Brain Res 47:202-214.

Zhang JH, Cerretti DP, Yu T, Flanagan JG, Zhou R (1996) Detection of ligands in regions anatomically connected to neurons expressing the Eph receptor Bsk: potential roles in neuron-target interaction. J Neurosci 16:7182-7192.

Zhou R (1998) The Eph family receptors and ligands. Pharmacol Ther 77:151-181.

Zisch AH, Pasquale EB (1997) The Eph family: a multitude of receptors that mediate cell recognition signals. Cell Tissue Res 290:217-226.

Zisch AH, Kalo MS, Chong LD, Pasquale EB (1998) Complex formation between EphB2 and Src requires phosphorylation of tyrosine 611 in the EphB2 juxtamembrane region. Oncogene 16:2657-2670. 